https://nv.nltu.edu.ua

https://doi.org/10.15421/40290513

$@ \bowtie$ Correspondence author

Article received 13.05.2019 p.

Article accepted 30.05.2019 p.

O. V. Speranska

УДК 630.232.22

speranska.ev@gmail.com

О. В. Сперанська, О. В. Кобець

Хортицька національна навчально-реабілітаційна академія, м. Запоріжжя, Україна

\title{
ПРОЕКТ БУДІВНИЦТВА ЕТНОПАРКУ В СЕЛІ ЧЕРВОНОКОЗАЦЬКЕ ЗАПОРІЗЬКОЇ ОБЛАСТІ
}

Зелений туризм - нове спрямування у світовому та вітчизняному туризмі. В Україні, зокрема і в Запорізькому регіоні, $\epsilon$ величезний потенціал для розвитку зеленого туризму. Тому в с. Червонокозацьке, у 52 км від Запоріжжя, планують створити "Парк історичних та етнографічних періодів". Ініціатором цього проекту є Інеса Носенко, голова запорізького центру "Мазал-тов", яка запросила викладачів та студентів Хортицької національної навчально-реабілітаційної академії взяти участь у проектуванні оформлення ділянок-садів у стилях, властивих різноманітним етносам. Розроблений проект "Парку історичних та етнографічних періодів" за умови реалізації дасть змогу створити колоритний, цікавий ландшафтний об'єкт, який буде комфортним місцем відпочинку для місцевих, міських мешканців, туристів зі всієї України та 3-за кордону. Водночас він стане ландшафтним музеєм просто неба. Відвідування садів-ділянок, оформлених у різноманітних стилях сучасної ландшафтної архітектури, дасть змогу доторкнутися до культури різних народів та епох. "Античний сад" - один із таких цікавих, загадкових і привабливих куточків, який занурить відвідувачів у атмосферу давньої Греції, познайомить 3 архітектурою і рослинністю сонячного Пелопонесу. Майбутній Парк має привернути увагу вітчизняних та зарубіжних туристів, інвесторів, меценатів, що сприятиме економічному розвитку регіону, забезпечить нові робочі місця для місцевих мешканців $\mathrm{i}$ покращить естетичний та санітарно-екологічний стан території проектування.

Ключові слова: зелений туризм; етнографічне село; етнографічний майстер-клас; стилі ландшафтної архітектури; парк відпочинку.

Вступ. Село Червонокозацьке розташоване у Вільнянському районі Запорізької обл. у степовій зоні, суббореального семіарідного типу суші, на рівнинній території. Клімат - помірно континентальний. Зручне географічне положення, м'який клімат і природне багатство краю створили тут сприятливі умови для життя людини. У межах Програми розвитку рекреаційно-курортного комплексу та туризму в Запорізькій обл. до 2020 р. заплановано створення у цьому селі "Парку історичних та етнографічних періодів".

Площа території майбутнього етнопарку становить 6,878 га та має прямий ухил $0,03^{\circ}$ західної та південної експозиції, що характеризує сприятливі умови дренажування. Також на території парку розташований водний об'єкт - загата, який з'єднаний з річкою Любашівка. Водне живлення загати здійснюється завдяки атмосферним опадам і підземним водам. Береги загати укріплені гранітним каменем. Перед початком проектних робіт було ретельно обстежено територію (Speranska \& Kobets, 2018, pp. 38-41).

Викладення основного матеріалу. Під керівництвом авторів статті студенти відділення "Ландшафтний дизайн" Хортицькой академії розробили загальний проект "Парку історичних та етнографічних періодів". Загальний план благоустрою та озеленення представлено на рис. 1. Проектом передбачено розподіл території на окремі зони - сади, кожен з котрих має бути оформле-

ний у певному стилі ландшафтної архітектури: англійському, італійському, французькому, античному, східному, кантри стилях (Teodoronskij \& Bogovaja, 2003). На території також з'являться монастирський, романтичний, сад у стилі "модерн", а також алея майстрів, дитячий та спортивний майданчики та велотрек. Берегову лінію ставка запропонували замостити терасною дошкою та спорудити пірс для занять спортивною рибалкою, а також влаштувати причал для човнів, на яких можна було б відпочити на воді.

За допомогою аналізу географічного положення i кліматичних умов було визначено, що об'єкт озеленення знаходиться в зоні, яка забезпечує успішне вирощування рослин, властивих регіонам Греції, Франції, Італії (Nekhuzhenko, 2004). Також було визначено, що під'їзд транспорту від автомагістралі до об'єкта не утруднений, за винятком зимового періоду під час снігопаду. Але водночас дорожнє покриття не відповідає нормативним вимогам до їх транспортно-експлуатаційного стану. Цей чинник, на жаль, може негативно позначитися на туристичному аспекті "Парку історичних та етнографічних періодів".

Однією 3 найцікавіших ділянок парку має стати "Античний сад", який розташовуватиметься біля в'їзду в парк (ділянка 12), проектне рішення якого запропонував студент відділення "Ландшафтний дизайн" К. А. Сурело Візуалізацію виконав в комп'ютерній програмі

Інформація про авторів:

Сперанська Олена Володимирівна, викладач, кафедра садово-паркового господарства. Email: speranska.ev@gmail.com

Кобець Оксана Валентинівна, канд. с.-г. наук, ст. викладач, кафедра садово-паркового господарства.

Email: kobets1oks@gmail.com

Цитування за ДСту: Сперанська О. В., Кобець О. В. Проект будівництва етнопарку в селі Червонокозацьке Запорізької області. Науковий вісник НЛтУ України. 2019, т. 29, № 5. С. 66-68.

Citation APA: Speranska, O. V., \& Kobets, O. V. (2019). A Construction Project of the Ethnic Park in Chervonokozatske Village Zaporizhzhia Region. Scientific Bulletin of UNFU, 29(5), 66-68. https://doi.org/10.15421/40290513 
3Dmax. Сад в античному стилі відмінно виглядатиме у загальному композиційному настрої етнопарку і не матиме труднощів з підбором рослин, пов'язаних із кліматичними умовами.

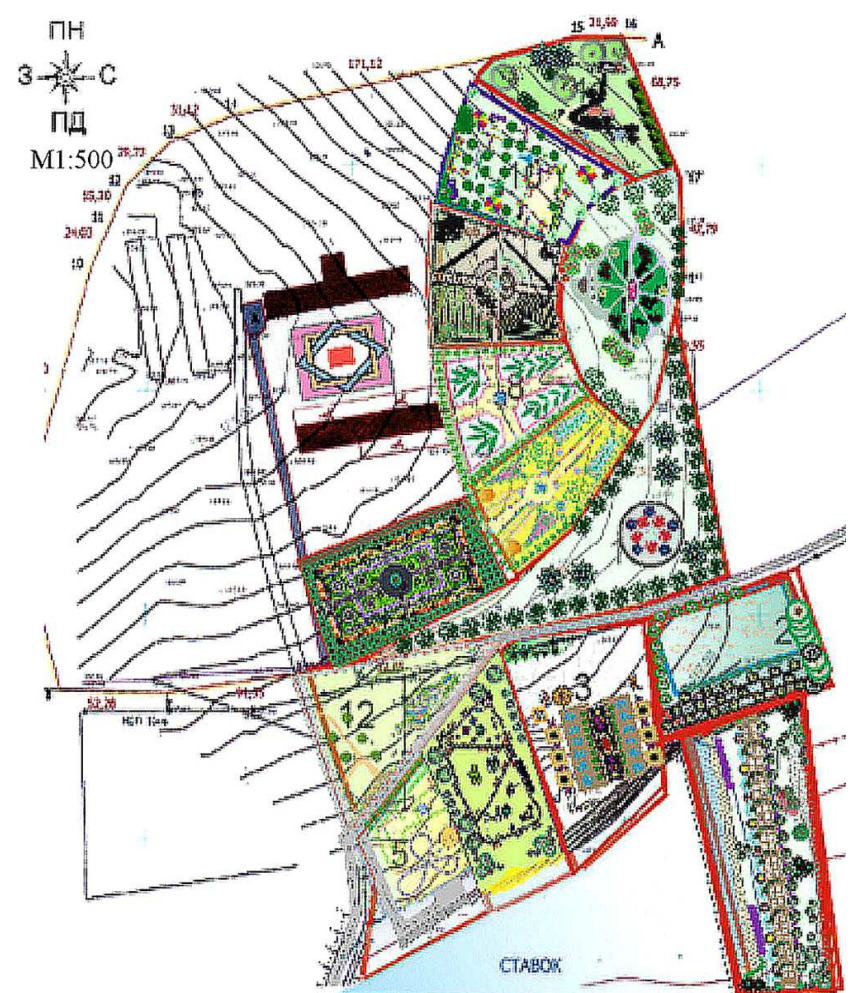

Рис. 1. План благоустрою території етнопарку в с. Червонокозацьке Запорізької обл.

Проектована ділянка оточена трьома дорогами, тому особливістю планування було розміщення насаджень так, щоб з будь-якого місця огляду ділянка благоустрою мала привабливий вигляд. На території об'єкта розташовано розподільчий вузол електроліній, що порушує загальне естетичне композиційне сприйняття пейзажу, тому було рекомендовано вирішити питання щодо маскування цих інженерних споруджень.

Загальна композиція ділянки складатиметься 3 кількох характерних елементів: архітектурні споруди будуть мати вигляд фрагментів стін будівель (рис. 2); майданчик матиме покриття, стилізоване під стародавню бруківку; обов'язкова наявність колон; невелика ділянка саду з маслинки вузьколистої та кам'янисто-квіткова композиція додасть життя і барв стилізованим руїнам. Колірна гама архітектурних елементів і грецькі рослини-аборигени дадуть змогу відчути жаркий клімат і яскраве сонце, властиве грецькому регіону.

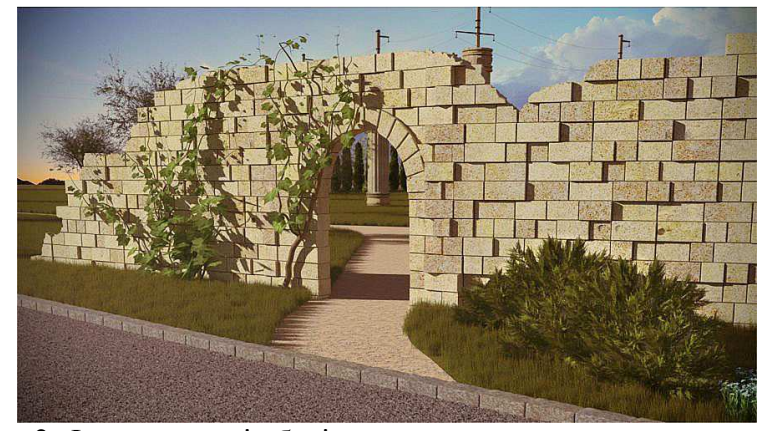

Рис. 2. Фрагменти стін будівель

На розі біля в'зду на ділянку запропоновано розташувати яскравий квітник площею $34,5 \mathrm{~m}^{2}$, засаджений проліскою дволистовою (лат. Scilla bifolia) та нарцисом вузьколистим (лат. Narcissus poeticus). Квітник має оточити ялівець лускатий (лат. Juniperus squamata 'Blue Carpet') і костриця валісська (лат. Festuca valesiaca) (рис. 3).

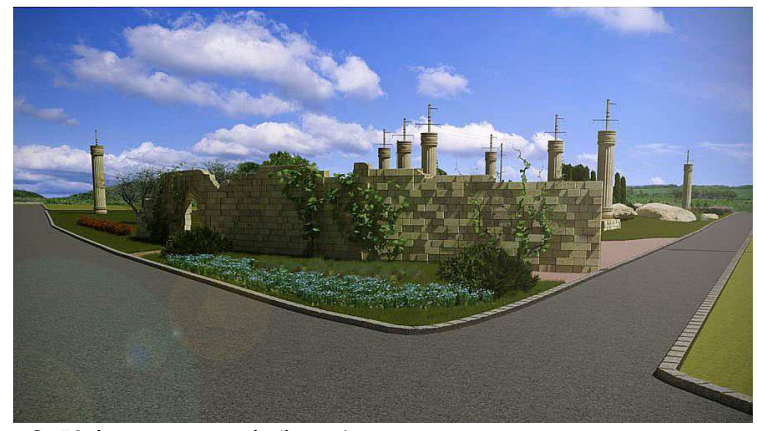

Рис. 3. Квітник на розі біля в"їзду

Фоном квітника буде декоративна стіна, увита виноградом Віча. Далі по східній експозиції ділянки вздовж дороги за декоративною стіною заплановано розташувати майданчик, що має нагадувати частину агори і бути викладеним зі стилізованої бруківки. У північно-західному напрямку від нього спроектовано "зарослу" доріжку з дрібного щебеню, що пройде крізь рядове насадження маслинки вузьколистої (лат. Elaeágnus angustifólia), що додасть ще більше "грецького" колориту. Розташовані в центрі ділянки стовпи ЛЕП, за проектом, мають бути стилізовані під стародавні колони і повиті виноградом Віча (лат. Parthenocissus Veitchii) (рис. 4).

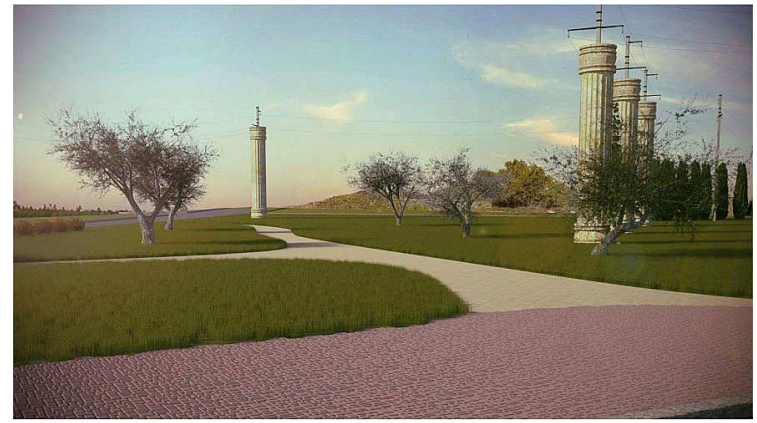

Рис. 4. Стовпи електромереж, стилізовані під давньогрецькі колони

У східній частині ділянці об'єкта озеленення спроектовано кам'янисто-квіткову композицію (Pushkar, 2007).

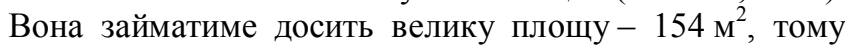
навіть на відстані кількох десятків метрів вона привертатиме до себе увагу відвідувача та буде відволікати його погляд від непривабливого вузла електроліній.

До складу композиції увійдуть хвойні рослини ялівці, а саме: ялівець скельний (Juniperus scopulorum 'Skyrocket'), ялівець горизонтальний (Juniperus horisontalis 'Blue Chip', Juniperus horisontalis 'Lime Glow'), ялівець звичайний (Juniperus communis 'Gold Cone'), ялівець лускатий (Juniperus squamata 'Blue Carpet') (Kohno, 1986). Зокрема, ялівець скельний заплановано висадити рядовим насадженням для маскування стовпів ЛЕП i створення прекрасного фону для кам'янисто-квіткової композиції. У ії склад увійдуть такі багаторічники, як: айстра новоанглійська (лат. Aster novae-angliae), шафран Томмасіні (лат. Crocus tommasinianus 'Roseus'), нарцис вузьколистий (лат. Narcissus poeticus), нарцис жовтий (лат. Narcissus pseudonarcissus), флокс шилоподібний (лат. Phlox subulata), проліска дволиста (лат. Scilla 
bifolia), гвоздика-трав'янка (лат. Diánthus deltoídes), горлянка повзуча (лат. Ajuga reptans) (Bobyleva, 2010). Прекрасним доповненням дизайну античного саду стануть камені різного розміру: від величезних валунів до невеликих каменів. Такі злаки, як костриця валісська (лат.Festuca valesiaca) і міскантус китайський (лат. Miscanthus sinensis 'Zebrinus'), надаватимуть композиції природності (рис. 5).

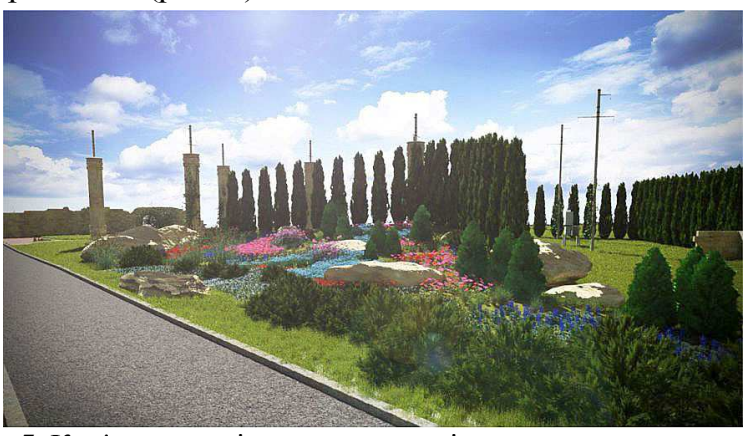

Рис. 5. Кам'янисто-квіткова композиція

На розі перетину двох доріг запропоновано розмістити квітник $з$ айстри новоанглійської (лат. Aster novaeangliae) і нарциса вузьколистого (лат. Narcissus poeticus), а також трьох ялівців лускоподібних (Juniperus squamata 'Blue Carpet'). Оскільки ділянка має ухил у бік в'їзду на територію парку, то погляд відвідувача відразу зупиниться на цій композиції.

На північній експозиції ділянки заплановано висадити в ряд ялівець скельний (Juniperus scopulorum 'Skyroc$\left.k e t^{\prime}\right)$ та встановити невисокий фрагмент стилізованої під руїни стіни, від якої вглиб ділянки має тягнутися квітник 3 айстри новоанглійської (лат. Aster novae-angliae). Композиція цих трьох елементів приховає непривабливий вигляд на стовпи ЛЕП, а також доступ до них.
Висновки і перспективи. Запропоноване проектне рішення "Парку історичних та етнографічних періодів" за умови реалізації дасть змогу створити колоритний, цікавий ландшафтний об'єкт, який буде комфортним місцем відпочинку для місцевих, міських мешканців, туристів зі всієї України та 3-за кордону. Водночас він стане ландшафтним музеєм просто неба. Відвідування садів-ділянок, оформлених у різноманітних стилях сучасної ландшафтної архітектури, дасть змогу доторкнутися до культури різних народів та епох. "Античний сад" - один із таких цікавих, загадкових і привабливих куточків, який занурить відвідувачів у атмосферу давньої Греції, познайомить 3 архітектурою і рослинністю сонячного Пелопонеса.

Майбутній Парк має привернути увагу вітчизняних та зарубіжних туристів, інвесторів, меценатів, що сприятиме економічному розвитку регіону, забезпечить нові робочі місця для місцевих мешканців і покращить естетичний та санітарно-екологічний стан території проектування.

\section{Перелік використаних джерел}

Bobyleva, O. N. (2010). Flower-decorative plants of open ground. (2nd ed.). Moscow: Akademija. [In Russian].

Kohno, N. A. (Ed.). (1986). Trees and shrubs cultivated in the Ukrainian SSR. Kyiv: Scientific thought. [In Russian].

Nekhuzhenko, N. A. (2004). Basics of landscape design and landscape architecture. St. Peterburg: Neva. [In Russian].

Pushkar, V. V. (2007). Flower garden design. Kyiv: Alterpres. [In Ukrainian].

Speranska, O. V., \& Kobets, O. V. (2018). Project of the construction of the park of historical and ethnographic periods in the village of Chervonokozatskoe, Zaporizhzhia region. Scientific Bulletin of $U N$ FU, 28(11), 38-41. https://doi.org/10.15421/40281107

Teodoronskij, B. C., \& Bogovaja, I. O. (2003). Objects of landscape architecture. Moscow: MGUL. [In Russian].

\section{O. V.Speranska, O. V. Kobets}

\section{A CONSTRUCTION PROJECT OF THE ETHNIC PARK IN CHERVONOKOZATSKE VILLAGE}

ZAPORIZHZHIA REGION

Green tourism is a new direction in world and domestic tourism. In our country, in particular, in Zaporizhzhya Region, there is a huge potential for the green tourism development. Therefore, it is planned to create the Park of Historical and Ethnographic Periods in the village of Chervonokozatske, $52 \mathrm{~km}$ from Zaporozhzhya. The initiator of this project is Inessa Nosenko, the Head of Zaporizhzhya Center Mazal-Tov, who invited teachers and students of the Khortitsia National Educational Rehabilitation Academy to take part in the garden design in styles, typical of various ethnic groups. The project "Park of Historic and Ethnographic Periods" will allow creating a colorful, interesting landscape object, which will serve as a comfortable place for rest for local city residents, tourists from all over Ukraine and from abroad. At the same time, it will become an open-air landscape museum. Visiting the gardens decorated in various styles of modern landscape architecture will allow tourists to touch the culture of different peoples and epochs. The Antique Garden is one of such interesting, mysterious and attractive corners that will immerse visitors in the atmosphere of ancient Greece, acquaints with the architecture and vegetation of the solar Peloponnesus. Future Park should attract the attention of domestic and foreign tourists, investors, patrons, which will promote the economic development of the region, provide new jobs for local residents and improve the aesthetic and sanitary and ecological state of the designing area. The project provides division of territory into separate zones - gardens, each of which must be decorated in a certain style of the following landscape architecture: English, Italian, French, antique, oriental, country styles, etc. There will also be a monastic, romantic, modern style garden, as well as masters' alley, children's and sports grounds, and cycling track. The coastline will be offered to pile up a terraced board and build a pier for sports fishing, as well as arrange a boat moorage, where you can rest on the water. One of the most interesting parts of the park should be the Antique Garden, which will be located near the entrance to the park (section 12), the design decision of which was proposed by the student of the Landscape Design department, Surelo K. A. The visualization is done in the 3Dmax computer program. The general composition of the site will consist of several characteristic elements: the architectural structures will look like fragments of the walls of buildings (Fig. 2); the playground will be covered, stylized under the ancient pavement; obligatory presence of columns; a small part of the ornamental garden with a narrow, rocky and flower arrangement will add lifestyle and colour to stylized ruins. The colour scheme of architectural elements and Greek aboriginal plants will allow feelinng the hot climate and the bright sun, typical of the Greek region.

Keywords: green tourism; ethnographic village; ethnographic master class; styles of landscape architecture; recreation park. 